\title{
Demographic characteristics of patients a state hospital emergency service: meta-analysis of 2011
}

\author{
Bir Devlet hastanesi acil servisi hastalarının demografik özellikleri: 2011 yılı meta analizi
}

\author{
Kenan Ahmet Türkdoğan ${ }^{1}$, Mücahit Kapçı ${ }^{1}$, Orhan Akpınar ${ }^{1}$, Ali Duman ${ }^{1}$, Gülçin Bacakoğlu' ${ }^{1}$,
} Figen Tunalı Türkdoğan ${ }^{3}$, Mustafa Karabacak², S. Hakan Eren ${ }^{4}$, Abuzer Coşkun ${ }^{4}$

\begin{abstract}
Objective: The examination and treatment modalities should be measurable for improve the service quality of emergency service. This may be possible with the data collection system which is comprehensive and world-wide known. The aim of this study is to investigate the demographical features of patients who admitted to our service by computer based patient recording system and create a better service quality in the view of these data.
\end{abstract}

Methods: Registered 115,185 patients were included whom admitted to our service between January 2011 and December 2011. The demographic characteristics, symptoms, triage distributions, the average length of stay, consultation rates, hospital admission forms, hospitalization and discharge rates were classified according to the International Classification of Diseases-10 (ICD-10).

Results: The mean age of patients was $38.70 \pm 19.92$ years and $44.8 \%$ of the patients were male. Triage categories of the patients in category red, yellow and green $5.5 \%, 53.1 \%, 41.4 \%$, respectively. Patients older than 65 years old were 14,643 (12.7\%). Most common presentation day was Monday and the time period was between 20 p.m. and 24 p.m. The mean length of emergency service stay was 47 minutes, consultation and admission rates were $8.5 \%$ and $3.2 \%$, respectively. 1,876 patients of older than 65 years old were admitted to the services.

Conclusions: Emergency service admission registrations should be stored and analyzed by using the digital and sharable systems to serving a better qualified service in emergency services which provides continued service step to health care. This will allow the national standardization and determine the international location. J Clin Exp Invest 2013; 4 (3): 274-278

Key words: Emergency service, meta-analysis, demographic data, triage

\section{ÖZET}

Amaç: Acil serviste hizmet kalitesini artırabilmek için yapılan tetkik ve tedavi modalitelerinin ölçülebilmesi gerekmektedir. Bu da kapsamlı ve tüm dünyada tanınan bir dokümantasyon ve veri toplama sistemi ile mümkün olmaktadır. Bu çalışmanın amacı bilgisayar tabanlı hasta kayıt sistemi kullanılarak servisimize başvuran hastaların demografik özelliklerinin incelenmesi ve bu veriler ışığında daha kaliteli hizmet şeklini oluşturmaktır.

Yöntem: Çalışmamıza Ocak 2011-Aralık 2011 tarihleri arasında servisimize başvuran sisteme kayıtlı 115185 hasta dahil edildi. Hastaların demografik özellikleri, başvuru şikayetleri, triaj dağılımları, ortalama kalış süreleri, konsültasyon oranları, hastaneye başvuru şekilleri, yatış ve taburculuk oranları Uluslararası Hastalık Sınıflandırması-10 (ICD-10) tanı koduna göre sınıflandırıldı.

Bulgular: \%44,8'i erkek olan hastaların yaş ortalaması $38,70 \pm 19,92$ yıl idi. Hastaların triaj kategorilerine bakıldığında \%5,5'si kırmızı, \%53,1'ü sarı, \%41,4'sı yeşil başvurulardı. Hastaların 14643'ü $(\% 12,7) 65$ yaş üstü kişiler idi. Geliş zamanına göre en çok başvurunun yapıldığı gün pazartesi iken, en sık başvurunun yapıldığı saatler 20:0024:00 arasında idi. Hastaların acil serviste ortalama kalış süresi 47 dakika, konsültasyon oranı $\% 8,5$ ve yatış oranı $\% 3,2$ idi. Acile başvuran 65 yaş üstü hastaların 1876'sı servislere yatırıldı.

Sonuç: Sağlık hizmetlerine sürekli hizmet basamağı sağlayan acil servislerin daha kaliteli hizmet vermesi için, acil servis başvuru kayıtları dijital ve paylaşılabilen sistemlerde saklanmalı ve analizi yapılmalıdır. Bu ulusal standardizasyonu sağlayacak ve uluslar arası konumu belirleyecektir.

Anahtar kelimeler: Acil servis, meta analiz, demografik veri, triaj

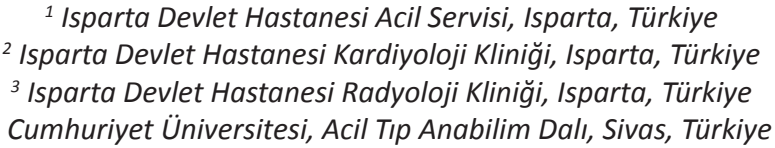

Correspondence: Kenan Ahmet Türkdoğan,

Isparta Devlet Hastanesi Acil Servisi 32040 Isparta, Türkiye Email: kenan-ahmet@hotmail.com

Received: 24.05.2013, Accepted: 20.06.2013

Copyright (C JCEI / Journal of Clinical and Experimental Investigations 2013, All rights reserved 


\section{INTRODUCTION}

In health sector, emergency service which work like a mirror are the most important unit that is concentric with the society in a region. All the hospital units must have full equipment for both human power and working occasion. Emergency service needs to give right, fast and uninterrupted service to the patients so it is different from other service. To give quality emergency service, it should give attention defining the region's condition and patient's portfolio and assistants equipments like tomography, magnetic resonance imaging (MRI) should be reached. If these conditions occur, there will be development in the staff and patients' pleasant $[1,2]$.

Changing in social-culture and rate of popular cause to patient density in Educational-search region hospital so that the service is hampered [3-5]. Consequently, it would bring along unpleasant, increasing waiting time and security problems $[5,6]$.

In Turkey, there are more than 1000 emergency services that give interrupted service [7]. In these emergency services, right data can't be reached because of wrong recording healthy patients, properties of patients and using material. This is the biggest problem for detection of cases.

Emergency service is a legal progress which starts with demanding of patients and going on with the directions of doctors and ending with the decision of doctors. So doing especially recording documentaries are so important. Difference of clinical complains of patients make the different demands from emergency service [1]. So settlement of emergency service and type of working effect the quality of service it should be compared and evaluated with the system that is accepted all over the world.

Nowadays keeping the data in different place, separating health institution, state hospitals, 112 emergency health service and folk health from each other make the data so complexity. These data should be evaluated and then come together. In USA even if there could be lost data, all data can be gathered in a center [8].

\section{METHODS}

This search is retrospective and definitions that was done from adult patients who applied the State Hospital emergency service and pediatric trauma patients' computer data of patient's record, between January 2011 and December 2011. The using documentary is taken from state hospital emergency service's patient records system.
In this process, 115,185 patients who applied were searched. From system records, according to the system of ICD-10 coding we could reach the applied patients' age, gender, applying date leaving hour, reason of applying, triage category, required consultations.

According to the data, patients demographic process (age, range of gender, dispersion of gender according to the patients' age group), triage categories, required range and dispersion of consultation, type of the patients' entering, results of patients, taken patients from the emergency service were examined respectively. Analyzing of the data was evaluated with Microsoft Excell for windows and Statistical Package for the Social Sciences version 15.0 for windows (SPSS Inc., Chicago, IL, USA) statistical package program. In analysis' frequency (number) and percent, Chi-square test was used.

\section{RESULTS}

115,185 patients who applied the department were recorded and these recordings were evaluated. The average of patient's age was $38.70 \pm 19.92$. When examining the number of patients according to the months, January had the most density in patient's number. The number of applying according to the months was emphasized in Graphic 1.

When examining the range applying according to gender, $51,602(44.8 \%)$ patients of all the applying patients were male, and 63,583 (55.2\%) were female. $6,335(5.5 \%)$ patients were in red category, 61,209 patients $(53.1 \%)$ in yellow category, 47,641 $(41.4 \%)$ in green category. When the examining the consultation which were wanted from emergency service, the most consultation were from Orthopedics department.

In a year, it was determined that 13,821 consultations were required from 9,146 patients $(8.5 \%)$ of 115,185 patients. Exterior from emergency service, three sections which required mostly consultation were Orthopedics $(n=1,745,12.6 \%)$, Cardiology $(n=1,618,11.7 \%)$, and Neurology $(n=1,609,11.7 \%)$.

The most applying density day is Monday $(14.2 \%)$, the least applying number is on Thursday $(10.2 \%)$. When investigating the number of patients, whose are sent in March.

During the studying, 608 patients of 115,185 patients were sent other institutions. Cardiology department was the mostly sending patients to other institutions. The most sending reasons were no angiography service, lack of intensive care unit, sometimes lack of field experts and having no psyche and nervous ailments department. 


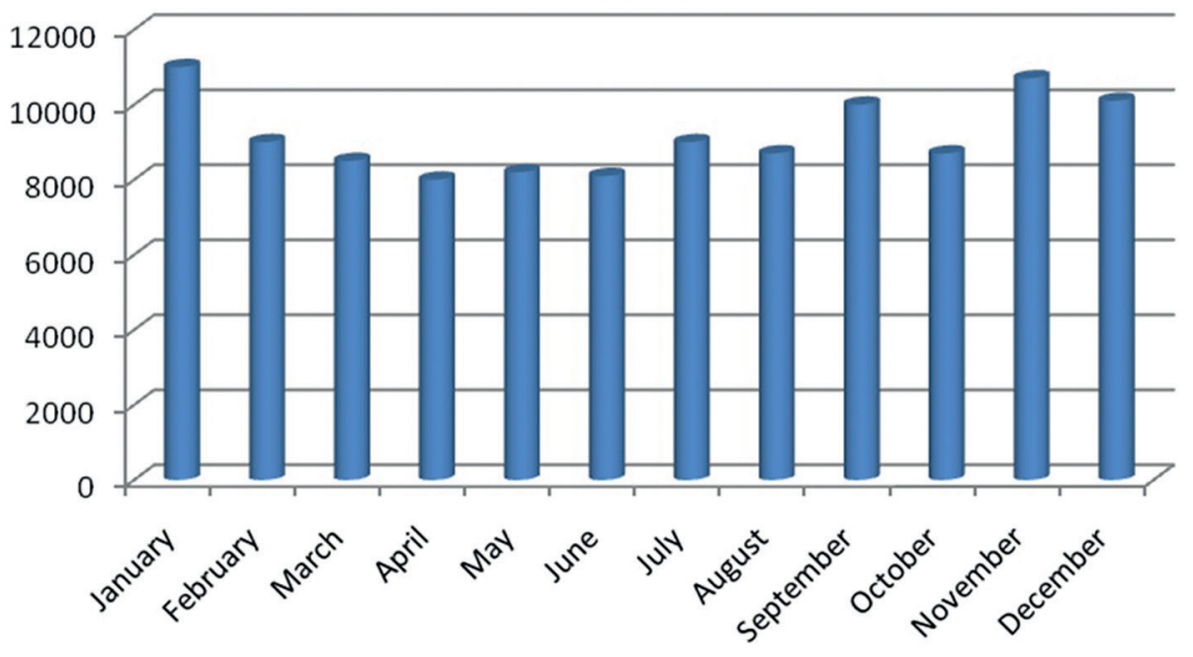

Graphic 1. The number of patients incoming the emergency department by month.
Table 1. The number of patients according to the diagnostic criteria.

\begin{tabular}{|c|c|c|c|}
\hline Application Diagnosis & $\mathrm{n}$ & Application Diagnosis & $\mathrm{n}$ \\
\hline URTI & 25,682 & Anemia & 900 \\
\hline Wound infection & 7,413 & Fever & 784 \\
\hline Myalgia & 7,285 & Gingivitis & 778 \\
\hline UTI & 6,721 & Sinusitis & 711 \\
\hline Hypertension & 5,249 & $\begin{array}{l}\text { Cerebrovascular } \\
\text { disease }\end{array}$ & 711 \\
\hline Peptic ulcus & 5,125 & Dysmenorrhea & 566 \\
\hline Sefalji & 4,203 & Asthma & 495 \\
\hline Lumbalgia & 3,484 & Arrhythmia & 487 \\
\hline Diarrhea & 3,378 & Hyperglycaemia & 420 \\
\hline Psychotic episode & 3,184 & Hemorrhoids & 335 \\
\hline Copd exacerbations & 3,057 & Epistaxis & 292 \\
\hline Abdominal pain & 2,940 & Insect bites & 279 \\
\hline Pain & 2,878 & Epilepsy & 274 \\
\hline Vertigo & 2,660 & $\begin{array}{l}\text { Myocardial } \\
\text { infarction }\end{array}$ & 274 \\
\hline Allergy & 2,440 & Drug poisoning & 272 \\
\hline Soft tissue disorders & 2,336 & $\begin{array}{l}\text { Congesive heart } \\
\text { failure }\end{array}$ & 230 \\
\hline Nausea and vomiting & 1,862 & Hypoglycaemia & 179 \\
\hline Renal colic & 1,732 & $\begin{array}{l}\text { Gastrointestinal } \\
\text { bleeding }\end{array}$ & 95 \\
\hline Conjunctivitis & 1,609 & $\begin{array}{l}\text { Carbon monoxide } \\
\text { poisoning }\end{array}$ & 42 \\
\hline Pneumonia & 1,584 & $\begin{array}{l}\text { Deep vein } \\
\text { thrombosis }\end{array}$ & 34 \\
\hline Migraine & 1,541 & Others & 12 \\
\hline \multicolumn{4}{|l|}{ Trauma Diagnosis } \\
\hline Extremity injury & 6,148 & Rabies suspicion & 446 \\
\hline Wound & 2,956 & $\begin{array}{l}\text { Foreign body } \\
\text { in eye }\end{array}$ & 239 \\
\hline Head injury & 1,774 & Stab wounds & 66 \\
\hline Beaten & 938 & $\begin{array}{l}\text { Foreign body } \\
\text { in ear }\end{array}$ & 53 \\
\hline Burn & 781 & $\begin{array}{l}\text { Foreign body } \\
\text { in nose }\end{array}$ & 48 \\
\hline Foreign body & 518 & Gunshot wounds & 29 \\
\hline
\end{tabular}

URTI: Upper respiratory tract infection, UTI: Urinary tract infection
When giving attendance to the type of applying, it is determined that 111,648 patients $(96.9 \%)$ of 115,185 patients come the department by themselves, 3,537 patients come with ambulance. While 2,972 patients of 3,637 patients were taken directly from their home, 565 patients were brought to our service from the other hospital. When to examine the numbers of patients who hospitalized, according to the month July was the most density month.

It is emphasized that after the evaluating of patients in emergency service, when the investigating the diagnoses, 110,497 (95.9\%) patients discharged from hospital after examining of emergency service and $3,649(3.2 \%)$ patients were taken the hospital. The number of dying patients was $51(0.04 \%)$. After entering the emergency service, the number of patients who left the emergency service at any evaluating stage or before evaluating was 380 (0.33\%). The patients who examined in emergency service were taken mostly to breath illness $(n=634,17.4 \%)$, internal medicine $(n=583,16.0 \%)$, neurology $(n=553,15.15 \%)$, general surgery $(n=527,14.4 \%)$, and cardiology ( $n=455,12.5 \%)$.

When the evaluating the reasons of applying, the most complaining were detected just as sore throat $(n=25,682,20.0 \%)$, muscle ache $(n=7,285$, $5.7 \%)$, stomach ache $(n=5,125,4.0 \%)$, breath ache $(n=3,914,3.1 \%)$, out of breath ache $(n=3,552$, $2.8 \%$ ). The other all diagnoses are shown in Table 1. The diagnoses were recorded into the data proceeding program according to the ICD-10 diagnoses coding systems. Because of the some patients having more than one diagnose, 115,185 patients were decided to totally 130,181 diagnoses.

\section{DISCUSSION}

According to the investigating 2011 our hospital's data, most of the applying occurs young adults 
and middle age patients and average of age is $38.70 \pm 19.92$. The most of the applying is middle age group and this resemblance-ness to USA data [9]. According to the Center for Disease Control (CDC), the national ambulatory medical care survey's investigating data, it is shown that applying in emergency service average age is 35.6 and from 1992 to 2002, average age increase at 8\% [10].

The reasons of the high average age who apply the emergency service may be not including children who haven't trauma. Not including the children who haven't trauma in that study is the reason of high average patient's age. When the observing age dispersion, it is shown that in childhood there are intensive at 2-5 age group. With the examining patient diagnoses, the reasons of this are thought that because of falling at that age.

When observing the relationship between age groups and gender, 0-19 age male patients' applies are more often. Joyce and colleagues state hospital in the emergency pediatric patients study that most of the patients are male (56\%) [11].

In 2002, the literature published in California said that the average staying time at emergency service was 59 minutes. But this literature also emphasized that $42 \%$ of patients had to wait at least an hour for any doctor who would examine them. According to the CDC's data in 2002, in USA staying time at emergency service is 3.2 hours and of patients wait at service for 1 to 6 hours [10]. The most important reason of this is the problems of taken hospital just as in the other studies.

When examining the triage categories, it is observed that $6,335(5.5 \%)$ patients applying to the emergency are red, 61,209 (53.1\%) patients are yellow, 47,641 (41.4\%) are green. Oktay and colleagues show in their study that $31.2 \%$ of patients applying to the emergency are not suitable for the emergency service [12]. Gill Jm state hospital that using emergency service inconveniently change from $5 \%-82 \%$ [13].

In Niska and colleagues' study, in 2007, 15.5\% of the patients applying to the emergency service are made with ambulance [14]. This rate is found as $3.1 \%$ in our study. At this study, the people who applied to the emergency service were 15-64 age groups and $55.3 \%$ patients of these groups were female, $44.7 \%$ of the patients were male. The often meeting complains are gastrointestinal complain which is $8.6 \%$, breath ache which is $5.8 \%$ and headache which is $3.6 \%$. In the geriatric age group (>65 years), the often meeting complains are breath ache which is $8.6 \%$, out of breathe ailment which is $6.3 \%$ and gastrointestinal complains which are $6.3 \%$.

In Singal and colleagues' study, they detected that old people usually apply for not so emergency conditions [15]. However this study shows that old people's complains are more acute and serious, their staying time at emergency service is much more and the rates of old people taking hospital are so high. And this shows us that it must be more carefully when taking history. Because Kılıçaslan and colleagues' study emphasize that old people usually apply the hospital for the emergency reasons [1]. In that study, the rates of inconvenient using between young and old patients are found different. That result resemblance to our study's results. When examining the triage categories, male situation. The reasons of this difference, male works much more and have no time so they could be applying to the hospitals just for emergency conditions.

In our study, average time of staying at emergency service is 1.8 hours. But this time can be extended because of consultations or survey depending on the patients' clinical condition and the problem of finding bed in the convenient department for taken patients. Oktay and colleagues are found the staying time in service is 3.3 hours [16].

In the studies it is shown that patients who should be taken hospital make the emergency service increase the rate of crowded $[6,17]$. Even though the rate of taken patients to our emergency service is $3.17 \%$, the average staying time in our service is shorter than other service in our country. Because hospital secretary authorize the emergency experts for using any free bed in hospital and it is accepted all the other services.

Lots of studies emphasize to decrease the intensiveness in emergency service, firstly the service should be empowered and the numbers of nurse and bed should be raised $[8,18,19]$.

In 1985, the study in USA state hospital that $10 \%$ of patients come to hospital with ambulance [20]. But in our study, 3.537 (31\%) patients come to hospital with ambulance was detected.

The rate of required consultations from emergency service is $8.46 \%$ and this rate can be changed depending on the applying properties, responsible emergency expert' and crew' clinical information experiences and emergency technical services.

When evaluating the patients' diagnoses, the most frequent illness is top (19.72\%) respiratory tract. It was seen that between the top respiratory tract patients, most of them are young adults. These 
results are similar with 2002 NHACMS' results. When evaluating the patients' results, it was found that the most of the patients $(95.9 \%)$ were treated on standing and discharged from hospital and the rate of taking patients was $3.17 \%$.

The studies in emergency service in Ankara show that the rate of discharged patients are given in the following; in Ankara Emergency service's rate is $58.2 \%$, Numune State Hospital emergency service's rate is $95.3 \%$, Hacettepe hospital emergency service's rate is $95.4 \%$, emergency helping and traffic hospital emergency service's rate is $73.6 \%$ [1]. But this rate is found $95.9 \%$ in our study.

To increase the quality of emergency service that try to give troubles and constant department, it must be done a rescue plan for each service. Furthermore unbalanced in the level of income between health crew is a serious problem.

Consequently, to give a quality service, emergency service must be supported in rush hours, administration should support the emergency department for taking patients, a quality recording system and founding an archive in every city, fixing the unbalanced level of personal's incomes, when deciding the emergency service's physical conditions, emergency expert can advise and the environment where health personal can rest and these should be considered.

\section{Acknowledgement}

We thank to our hospital's data process center, automation system personals, Isparta 112 administrations manager and Secretary of Common Hospitals Union of Isparta for their helping us.

\section{REFERENCES}

1. Kılıçaslan İ, Bozan H, Oktay C, Göksu E. Türkiye'de Acil Servise Başvuran Hastaların Demografik Özellikleri. Türkiye Acil Tıp Dergisi 2005;5:5-13.

2. Holliman CJ. Designing a new emergency medicine facility. Acil Tıp Dergisi 2001;1:57-60.

3. Derlet RW, Kinser D, Ray L, et al. Prospective identification and triage of nonemergency patients out of an emergency department: A 5-year study. Ann Emerg Med 1995;25:215-223.

4. Afilalo M, Guttman A, Colacone A, et al. Emergency department use and misuse. J Emerg Med 1995;13:259264.
5. Andrulis DP, Kellermann A, Hintz EA, et al. Emergency departments and crowding in United States teaching hospitals. Ann Emerg Med 1991;20:980-986.

6. Baker DW, Stevens CD, Brook RH. Patients who leave a public hospital emergency department without being seen by a physician. JAMA 1991;266:1085-1090.

7. American College of Emergency Physicians. Hospital and emergency department overcrowding. Ann Emerg Med 1990;19:336.

8. Çımrın AH, Karcıoğlu Ö, Atilla R, et al. Acil Servis ve Akademik Acil Tıp. Dokuz Eylül Üniversitesi Acil Tıp Anabilim Dalı, İzmir, 2002;138-139.

9. McCaig LF, Burt WC. National Hospital Ambulotory Medical Care Survey: 1999 emergency department summary. Adv Data 2001;320:1-34.

10. McCaig LF, Burt WC. National Hospital Ambulotory Medical Care Survey: 2002 emergency department summary. Adv Data 2004;340.

11. Joyce SM, Brown DE, Nelson EA. Epidemiology of Pediatric EMS Practice: A Multistate Analysis. Prehospital and Disaster Medicine 1996;11:180-187.

12. Oktay C, Cete $\mathrm{Y}$, Eray $\mathrm{O}$, et al. Appropriateness of emergency department visits in a Turkish University Hospital. Croatian Medical Journal 2003;44(5):585591.

13. Gill JM. Non-urgent use of the emergency department: Appropriate or not? Ann Emerg Med 1994;24(5):953957.

14. Richard Niska, et al. National Hospital Ambulatory Medical Care Survey: 2007 emergency department summary. Adv Data 2010;26:2-21.

15. Singal BM, Hedges JR, Rousseau EW, et al. Geriatric patient emergency visits part I: Comparison of visits by geriatric and younger patients. Ann Emerg Med 1992;21:802-807.

16. URL: www.acep.org Fact Sheets. Emergency department waiting times: american college of emergency medicine.

17. Lambe $S$, Washington DL, Fink A, et al. Waiting time in California's emergency departments. Ann Emerg Med 2003;41:35-44.

18. Lynn SG, Kellermann AL. Critical decision making: Managing the emergency department in an overcrowded hospital. Ann Emerg Med 1991;20:287-292.

19. American College of Emergency Physicians. Measures to deal with emergency department overcrowding. Ann Emerg Med 1990;19:944-945.

20. Lowe RA, Goldfarb N, Berlin J, et al. Does access to primary care offices decrease emergency department use. Acad Emerg Med 1996;3:305-308. 